\title{
Conflict between government and the indigenous people of Chittagong Hill Tracts in Bangladesh
}

\author{
Iqthyer Uddin Md Zahed \\ $B$ A (Honours), M A (History), University Of Chittagong, Bangladesh \\ MBA, Anglia Ruskin University, UK
}

\begin{abstract}
This paper explores the struggle of indigenous people for their ethnic identity and conflict with Bangladesh government. The indigenous community was persecuted and deprived of human rights, basic needs from the British colonial periods. Internal displacement of aboriginals was started by the Pakistan government and continued till 1997.Land grabbing, Bengali settlement, internal displacements, ethnic non recognition in constitution of country, militarization of Chittagong Hill Tracts (CHT) and others issues made the indigenous people revolutionary and ultimately force them to demand autonomy of CHT. The conflicts between indigenous people and government came to end after signing Peace Accord of CHT in 1997 but non implementation of this incites the conflicts again what is being continued till now.
\end{abstract}

Keywords: Chittagong Hill Tracts (CHT), Conflict, Indigenous people, Hill People, Shanti Bahini (Peace Force), Government,

\section{Introduction}

The three hill districts of Bangladesh named Rangamati, Khagrachari, and Banderban together known as Chittagong Hill Tracts (CHT) that is the south eastern part of Bangladesh, bordering the Arakan and Chin States of Myanmar and the Tripura and Mizoram States of India. This region comprised of 13,295 kilometres which is one tenth of total country's land. About Thirteen indigenous communities live in the CHT and the people are of Sino-Tibetan descent belonging to the Mongoloid group and similar to the people of north east India, Myanmar, and Thailand rather than the people of the other parts of Bangladesh. Those communities are known as different names like Chakma, Marma, Pankho, Khumi, Lusai, Murong, Bonojog, Tanchanya, Khyang, Chak, Tripura, Mro, and Ryang. People call them Jummo or Pahari (The hill Men).The livelihood became changed simultaneously with the change of ruling body of the state. We try to depict the wave of their livelihood in three period of times like British colonial period in Bengal (1757-1947), Pakistan period (1947-1971) and Independent Bangladesh period (1971-onwords). The Hill people in CHT were very happy with the Act of CHT, 1900 (known as CHT Manual) which was made by the British government and made the CHT 'totally excluded area' from administration of the state. The conflict between indigenous people of CHT and government started from the Pakistan period (1947-1971). The Pakistan government built a Kaptai Hydro -Electric Dam at Chittagong in 1962. As a result of this project thousands and thousands of hill people became internally displaced and lost everything, many of them became refugee in India and Myanmar (Hussain, 1999). In Bangladesh period, the conflict come front because of rejecting to accept ethnic identity in Bangladeshi constitution. After long time of conflict the Peace Accord of CHT 1997 brought peace for the HT's people. But non implementation of this accord creates a new conflict between indigenous people and government of Bangladesh. This conflict is now not only limited with seeking identity but also include other issues like ownership of land and forest, resource use, settlement of non Bengali migrants and other socio-cultural, political and religious factors which exaggerate the situation even before.

\section{Historical Analysis of Conflicts}

Before the British rule in Bengal, CHT was the independent and sovereign territory. The hill people had own administrative and judicial system. In 1860 British East India Company put their attention to resources of CHT like cotton, trees, spices, food grains etc. In 1776 British military attacked CHT and the hill people fought strongly. This fighting between Chakma king and British army continued for a decades (Levene, 1999; Serajuddin, 1984). In 1887 the conflict ended when Lord Cornwallis and Chakma King Jan Box Khan agreed to sign a mutual agreement by giving right to British to do trade in HT. In 1860 the British declared CHT as a separate district from Chittagong. At the very beginning of $20^{\text {th }}$ Century, The British passed an act named 'CHT Regulation 1900' which is well known as Hill Tract Manual. In this regulation, CHT was divided into three circles and the community chief controlled the administration and judicial system. He was also responsible for collecting revenue and social security (Chakma, 2010). The CHT Regulation 1900 not allowed to sale the land to non tribal people and made restriction for settlement of Bengalis in CHT (Panday \& Jamil, 2009). The 
Bengalis, who intend to settle in HT, had to take prior permission of settlement from deputy Commissioner who had to take recommendation from Headman or Circle Chief. In this way CHT manual restricted the influx of non indigenous people in Hill Tracts. CHT Regulation 1920 declared CHT as an Excluded area and Independent from general administration. The King of CHT enjoyed complete autonomy by the government of India Act 1935 that declared CHT as 'Totally Excluded Area'.

In 1947 the British India was divided by two countries India and Pakistan on the basis of 'Two Nations Theory' that based on religious identity. As a Muslim state Bangladesh (then known as East Pakistan) was part of Pakistan. Pakistan was not concern about CHT and allowed the hill people to run their administration according to CHT Regulation 1900 till 1963. The army government of Pakistan made a constitutional amendment in 1963 which began to effective from1964. By this amendment the Bengalis (People from the plain area) had got chance to settle in CHT and the status of CHT area was changed from Excluded area to tribal area and the hill men to tribal people. The indigenous people and the Pakistan government had a clear conflict regarding this issue. Bengal was included with Pakistan due to religious similarity. According to CHT Manual, CHT was a sovereign territory and 97.2 percent indigenous people were non Muslim. So the HT people dislike the inclusion of the CHT with Pakistan (Chakhma, 2010). The Indian flag was erected in Rangamati and the Burmese flag in Bandarban after partition of India (Mey, 1984; shely, 1992). The Pakistani government treated this as a disloyal to state and recognized the hill people as anti Pakistani and pro Indian. The Pakistan government amended CHT manual several times to migrant the non hill people. The Abolition of the Act of 1900 and the construction of Kaptai project had considered as a starting point of conflict between CHT and the state.

\section{Kaptai dam and displaced hills people}

Bangladesh was part of Pakistan till 1971 due to impractical decision of British government. The Pakistan government took a project of hydro-electric dam at kaptai, Chittagong in 1960.The government made the dam without consulting local people. In 1962, when the project was ready to production, the water level rose and flooded the whole area. Thousands of people were displaced and lost their houses, agriculture lands and properties. About 400 square miles lands including 54,000 acres of cultivation lands that $40 \%$ of districts cultivation land went under water. About 100,000 indigenous people of CHT became refugee due to Kaptai dam and many of them became stateless in Tripura, Assam (Chowdhury, 2002). The government did not take any steps and did not pay any compensation to victims to rehabilitation. The displaced people for kaptai Dam were never regain their life like past time (Ali \& Tsuchiya, 2002). Most of the Jumma people think the major and starting cause of conflict with government is Kaptai Dam.

\section{Ethnic identity}

From very beginning of Bangladesh, the indigenous people facing the identity crisis. The ruling body of the country called them in different names in different times. They were known as a 'Hill Men' in British era and 'tribal' in Pakistan period. Since their ethnic identity was threatened in the very beginning of Bangladesh era and this was related to their role in liberation war of Bangladesh. Now try to trace back their position in the liberation war of Bangladesh.

There is a strong allegation against CHT people as a collaborator of Pakistan. It is true that some politician and Chakma King's activities were against Bangladesh. The leaders of CHT M. N. Larma and A.S. Pru Chowdhury did not give any clear decision about the liberation war of Bangladesh. The leadership of Awami League never show their interest about HT people to join in the war. In spite of few of them manage to engage themselves in the liberation war but most of them joined as a collaborator of Pakistani Army (Civil armed forces). Raja Tridiv, the Chakma Chief went to convention of United Nations as a member of Pakistan delegation to spread anti Bangladesh propaganda (Shelley 1992). Most of the common people were neither in favour of Bangladesh nor Pakistan except Chakma king (Uddin, 2005). The position of CHT people in Liberation war was one of the causes of their identity crisis. The Stranded Biharis of Bangladesh received same fate due to collaborating with Pakistani army in the Liberation war of Bangladesh (Zahed, 2013).

A delegation of CHT led by M. N. Larma met with the Prime Minister Sheikh Mujibur Rahman on 15 February 1972 and submitted four point charter of demand. Those were

i) Autonomy of the CHT with its own legislature;

ii) Retention of Regulation 1900 in the constitution of Bangladesh;

iii) Continuation of circle chiefs' offices; and

iv) A constitutional provision restricting the amendment of Regulation (Haq \& Haque, 1990)

The Prime Minister rejected the demands of the delegation of hill people and advised them 'to forget their ethnic identities' and assimilate with the new constitution of Bangladesh and accept the 'Bengali nationalism'(al- 
Ahsan \& Chakma, 1989). As a result of rejection of four charter of demand they established a Political party named Parbatya Chattagram Jana Samhati Samiti (United Peoples Organization of the CHT, PCJSS) lead by M.N. Larma. Shanti Bahini (Peace forces) was armed wings of it. In 1975 after assassination of Sheikh Mujibar Rahman, Larma went to India and organised guerrilla force named Shanti Bahini (Peace Force). Between 19751977 Shanti Bahini was organised and established as an armed organisation. As the Shanti Bahini was a revolutionary organisation, the Bangladesh government considered it threat for national security and national integration. The demand of autonomy of CHT and armed struggle against Bangladesh army was a significant threat of the new born country, Bangladesh.

The constitution of Bangladesh which finally approved in 1972, had not recognised the hill people. In the constitution of People's Republic of Bangladesh Article 9 Stated, "The unity and solidarity of the Bangalee (Bengali) nation, which deriving its identity from its language and culture, attained sovereign and independent Bangladesh through a united and determined struggle in the war of independence, shall be the basis of Bangalee nationalism". (Constitution of Bangladesh, 1972). In Article 3 (Part 1) stated about mother language of the country, "The state language of the Republic is Bangla". Article 6 (Part 1) stated about nationalism, "The people of Bangladesh shall be known as Bangalees as a nation and the citizens of Bangladesh shall be known as Bangladeshis". Manobendra Narayan Larma the president of PCJSS refused to accept Bengali nationalism according to constitution of Bangladesh. He stated disagreement in Parliament, "You cannot impose your national identity on others. I am a Chakma not a Bangali. I am a citizen of Bangladesh, Bangladeshi. You are also a Bangladeshi but your national identity is Bangali ... They (Hill People) can never become Bangali." (Parliamentary Debates, Government of Bangladesh,1972).

Prime Minister Sheikh Mujibur Rahman said at Rangamati in 1973 that the hill people known as bengalees and they would not bear any other identity (al-Ahsan \& Chakma, 1989). State refused to make category to recognise the minorities of country (Mohsin, 1997). The PCJSS was the result of rejection of ethnic identity by the state and persecution of tribal community by military wings of the state. Shanti Bahini (Peace Force) started operation in 1977. After the surprise attack of Shanti Bahini, the CHT region came under the General Officer Commander (GOC) of the Twenty-fourth Division of the Bangladesh Army and the Bangladesh army started the counterinsurgency operations. Thus, the life of hill people was in threat.

\section{Land and Migration Issue}

Prime Minister Sheikh Mujibur Rahman warned the delegation of CHT by saying that if they did not leave the autonomy demand of CHT, the government would arrange the resettlement of Bengali people in CHT (Schendel, 1992). Many Bangladeshi Refugees who returned home from India after the 1971 war were rehabilitated in the CHT (Kamaluddin, 1980). Government gave chance to the poor and landless people of different parts of Bangladesh to migrant in the CHT. About one hundred thousand landless Bengalis has been settled in CHT from 1979 to 1981 . And each Bengali settler family received 5 acres of hilly land or 4 acres of mixed land or 2.5 acres of paddy land (Shelly, 1992). There were many people settled in the CHT with their own afford. The non hill people were increased dramatically in HT areas. If we see the Table 1, In 1956 the non hill people was $9 \%$ of total population of CHT. The number of non hill people in HT was increased by about $50 \%$ in 1991. In contrast the number of indigenous people was decreased by $50 \%$ in the year of 1991 .

Table 1: The Population of CHT: hill Vs non-hill people (1872-1991)

\begin{tabular}{|l|l|l|}
\hline Year & Hill people (\%) & Non-hill people (\%) \\
\hline 1872 & 98.26 & 1.74 \\
\hline 1901 & 92.98 & 7.02 \\
\hline 1951 & 90.91 & 9.09 \\
\hline 1956 & 90.91 & 9.09 \\
\hline 1981 & 61.07 & 38.93 \\
\hline 1991 & 51.43 & 48.57 \\
\hline
\end{tabular}

Source: Adnan (2004)

The poor landless Bengali people and hill people are involve in fighting for ownership of land. CHT is an area of hills and forests. There is very little cultivable land in HT areas. Bangladesh government's plan to allocate 5 acres of hilly land or 4 acres of 'mixed' land, or 2.5 acres of paddy land to each Bengali family, it is quite impossible to allocate those large number of lands due to want of land in those areas. So the settler started to arrogate the land and homes of indigenous people. The settler had got the direct support from the administration and Bangladesh army. Thousands of indigenous people had been displaced from their home and crossed the boarder to take shelter in India. Table 1 shows the decreasing of indigenous people in Hill tracts. 


\section{Militarization in the CHT}

The CHT has officially controlled under militarization from 1977 onwards ( Mohsin, 1999). About 115,000 military person were positioned in the CHT which was one army person for every six hill people (Levene, 1999). Bangladesh was under military role from 1975 to 1990 which was one of the possible causes of militarization in CHT. Military took control of administration and development in there. Though the civil administration was present but all officers were military person. Military followed the role and divide strategy. They created small groups of hill people and put them on cluster villages. By this way the army was successful to maintain their control upon them and took them away from Shanti Bahini. Rights of information and movements were strictly controlled (Mohsin, 1997). The military officers were involve in rape, Killing, detention without trial, forced dislocation, etc. Major General Manzur, the Offier of Commanding, Chittagong Division Branch made statement 'We want the land and not the People' (Mohsin, 1999). The activities and the statement of Major General Manzur help to understand the relation between army and indigenous people of CHT.

\section{Religious and Cultural Belligerence}

As a part of their strategy, the army intentionally encourage the settler to marry hill girls by converting them to Islam. Al Rabita, a Saudi NGO is working in CHT and trying to convert poor hill people to Islam by offering food security, money, and jobs. Massacre and rape was carried out by Bangladesh army so that ethnic community could not support the Shanti Bahini but extending the Islam by converting indigenous people (Talukder, 2005). Table 2 shows the increasing rate of Islamic educational institutions in CHT due to Muslim settlers. The indigenous people complained about Muslim immigrants who tried to destroy culture, religion even their tribes. In some places immigrants are more dominant than hill people with strong back up from army and administration. Even though the settlers in CHT replaced the Chakma, Marma names of different places with Bengali and Muslim names (Table 3). It helps to understand the dominancy of non hill people of CHT.

Table 2: Growth of mosques and madrasas in the CHT

\begin{tabular}{|l|l|l|}
\hline Year & Number of Mosques & Number of Madrasas \\
\hline 1961 & 40 & 2 \\
\hline 1974 & 200 & 20 \\
\hline 1981 & 592 & 35 \\
\hline
\end{tabular}

Source: Mohsin (1999)

Table 3: The List of Changing the Names of Various Places of Khagrachari

\begin{tabular}{|l|l|}
\hline Previous name & Present name \\
\hline Bangal Kathi & Shantinagar and Muslim Para \\
\hline Pankheyoya Para & Milonpur, Pankhaiyapara, Kallanpur, Madampur \\
\hline Khagrapur & Islampur \\
\hline C.N.B Tila & Kadampur \\
\hline Kamal Chari & Battolla \\
\hline Khagrachari Bill & Anandapur \\
\hline Comilla Tila & Ambagan \\
\hline Kanoongo Para & Mohamadpur \\
\hline Uttda Chari & Rasulpur \\
\hline Paong Kabari Para & Fatemanagar \\
\hline Tai Kusum & Kalapani Chara \\
\hline Para Kalak & Lambapara \\
\hline
\end{tabular}

Source: (Nasreen: 2000)

\section{Peace Accord and its implementation}

The consecutive governments of Bangladesh took various steps to solve the problem between government and Shanti Bahini (Peace Force). But before 1997 their initiatives were not realistic and professionally sound. Most of the government tried to solve the problem by persecuting indigenous people using military where political commitment was totally absent. The economic and social development was nil for decades due to continuing rebellion. Every government treated the problem as threat of security of the country and searched the solution with accumulating military in CHT. The Awami Legue, one of the leading political party of Bangladesh made the government in 1996 and took the steps to mitigate the conflicts though nonmilitary ways. The national committee of the government was set up on October 1996 and the first meeting with PCJSS was held on December 1996. Finally the Peace accord was signed between Nation al Committee on behalf of government and PCJSS on December $2^{\text {nd }} 1997$. The major objectives of the peace accord were-

1. Protection of land rights of the hill people,

2. Stimulation of their cultural uniqueness,

3. Rehabilitation of internally displaced people and refugees who had left the country, 
4. Withdrawal of the military from the CHT (with the exception of permanent military establishments),

5. Self-government through regional and district councils were the main purpose of the signing the peace accord (Paul, 2004).

But all groups of hill people were not happy with this accord. The student wings supported by UPDF (United People's Democratic Front) rejected the accord and think that the accord was not able to address the fundamental right of hill people and they argued PCJSS have leaved the demand of autonomy of CHT. The accord is not fully implemented yet due to political commitment of governments. The one of the main sections of CHT peace accord 1997 was about withdrawal of Bangladesh army from CHT. Despite of agreeing to withdraw the temporary military camp from HT but only 152 out of 543 had been withdrawn so far. (UNPO, 2008)

Bangladesh Nationalist Party and Bangladesh Jamat e Islami, the two political parties of Bangladesh rejected the accord arguing that it is a threat to independence and sovereignty of the country. As BNP and its allies constitute the government in the year of 2001, the implementation of accord was stopped for a few years and BNP government took go slow strategy. The internal conflict of CHT specially PCJSS and UPDF were triumph up due to non implementation of Accord (Daily Star , 2004). The BNP complained for giving more autonomy to the CHT region which is contradicts with Constitution of Bangladesh and marked it as a 'Black Pact'.

There were some limitations of accord of CHT. At the very first stage secrecy was maintained very strictly by the time of negotiation between Shanti Bahini (Peace Force) and representatives of government. So there were no scopes to intellectuals to analyse the issues like division of responsibilities, sharing of power and leadership of regional councils etc. Mutual trust was absent among the responsible bodies related to the accord. BNP and Bengali settler in CHT did not welcome this accord and not cordial to implementation it. After signing the Accord there are conflict between PCJSS and other groups of Hill people who strongly believe the accord was failed to fulfil the full autonomy of CHT. Those hill people demands separate autonomy of CHT. The BNP stated it two countries in a one Motherland. The conflicts between hill people and settlers are still present in HT. Regarding the Accord issue the PCJSS and UPDF made a communal conflict on December 1998, in this conflict about 500 people were killed. UPDF followed the Kidnapping Strategy. About thousands of people were kidnapped in last decades. PCJSS also came on road for implementing the agreement. On the other hands the security forces arrest the members of PCJSS and UPDF. So those two groups of HT have set target for kidnapping and killing the members of security forces and Bengali settlers. (Amnesty International, 2000)

\section{Concluding Statement}

The ethnic minorities are deprived in many countries over the world. Similarly the indigenous people of the CHT struggled for their ethnic identities. They had shown their eagerness to get recognition of their identities by disobeying the constitution of Bangladesh. Shanti Bhini (Peace Force), the armed wings of hill people declared fighting against Bangladesh army. The life of people was under the trigger of Bangladesh Army and Shani Bahini (peace force) cadres. In the British colonial period they had known as a hill people (Pahari). They renamed as tribal people during the Pakistan era. In the time of Bangladesh period they are identified in Bengali word Upajatee (Sub-Nation). After the signing of Peace Accord of CHT in 1997, the people of CHT who were called by tribes now they known as ethnic minorities by amendment of constitution. If objective of a treaty is not achieved, it is considered as an unsuccessful treaty. The Peace accord of CHT 1997 is an example for the countries of South East Asia. It is true that the Peace Accord of CHT able to bring peace in HT for few days. The treaty was not implemented fully due to political honesty of Bangladesh governments. As a consequence of non implementation of this accord the indigenous people became divided and stated again revolutionary activities. Conflict between government and them grew up again. The government of Bangladesh need to implementation the accord fully and all institutions should be established and function properly according to the Peace accord.

\section{References}

[1]. Al-Ahsan, A. and Chakma,B. (1989) Problems of national integration in Bangladesh: the Chittagong Hill Tracts, Asian Survey, 29(10), pp. 959-970

[2]. Adnan,S. (2004). Migration, Land Alienation and Conflict: Causes of Poverty in the Chittagong Hill Tracts of Bangladesh (Dhaka, Bangladesh: Research and Advisory Service

[3]. Amnesty International, (2000) "Bangladesh: Human Rights in the Chittagong Hill Tracts", at $<$ http://asiapacific.amnesty.org/library/Index/ENGASA130012000?open \&of=ENG-BGD>

[4]. Chakma, B. (2010) The post-colonial state and minorities: ethnocide in the Chittagong Hill Tracts, Bangladesh, Commonwealth \& Comparative Politics, 48:3, 281-300, 
[5]. Chowdhury, B.H. (2002). Building Lasting Peace: Issues of the Implementation of the Chittagong Hill Tracts Accord, Program in Arms Control, Disarmament, and International Security (ACDIS) Occasional Paper series, University of Illinois at Urbana Champaign,Constitution of the People's Republic of Bangladesh, 1972, Dhaka: B.G. Press

[6]. Haq, S.and Haque, E. (1990). Disintegration Process in Action: The Case of South Asia, Dhaka: Bangladesh Institute of Law and International Affairs, pp. 44- 46

[7]. Hussain S. A. (1999), War and Peace in the Chittagong Hill Tracts: Retrospect and Prospect, Agamee Prakashani, Dhaka,

[8]. Kamaluddin, S. (1980). A tangled web of insurgency, Far Eastern Economic Review, 23-29 May.

[9]. Levene, M. (1999). 'The Chittagong Hill Tracts: A Case Study in the Political Economy of "Creeping" Genocide', Third World Quarterly 20 (2): 339-69.

[10]. Mey, W. (1984) . Implication of National Development Planning for Tribal Concept of Economy and Politics: A Contribution to a Critique of Concept of Development, Mahmud Shah Qureshi (ed.), Tribal Cultures in Bangladesh, pp. 325-337.

[11]. Mohsin, A. (1997). Militarisation and human rights violations in the Chittagong Hill Tracts. Paper presented at an International Peace Conference on Chittagong Hill Tracts in Bangkok, 23-26 February, 1997

[12]. Mohsin, A. (1999). The Politics of Nationalism: The Case of the Chittagong Hill Tracts,Bangladesh (Dhaka, Bangladesh: University Press).

[13]. Nasreen, Z. (2000). Rastraw, Jatiotabad O Protirod, (in Bengali) Unpublished M.S.S Thesis, Department of anthropology, University of Jahangirnagar, Savar, Dhaka

[14]. Paul S. C. (2004). Chittagong Hill Tracts: Stating and Resolving the Issues within the Mountains (Dhaka, Bangladesh: American International School/Dhaka, Senior Project, 2004).

[15]. Panday, P. K. and Jamil, I. (2009), Asian Survey, Vol. 49, No. 6 (November/December 2009), pp. 1052-1070

[16]. Parliamentary Debates, Government of Bangladesh, Dhaka, October $31^{\text {st }}, 1972$,

[17]. Schendel,W. V. (1992). The invention of the 'Jummas': state formation and ethnicity in Southeastern of Bangladesh, Modern Asian Studies, 26(1), pp. 95-128.

[18]. Serajuddin, A.M. (1984). 'The Chakma Tribes of the Chittagong Hill Tracts in the Eighteenth Century', The Journal of the Royal Asiatic Society of Great Britain and Ireland 1: 90-98.

[19]. Shelley, M. R. (1992). The Chittagong Hill Tracts of Bangladesh: The Untold History. Dhaka: Centre for Development Research.

[20]. Talukder, U. (2005). International Conference on Civil Society, Human Rights and Minorities in Bangladesh, January 2005, http://www.unpo.org/article/1927\#sthash.HbMV3BQE.dpuf

[21]. The Daily Star, Dhaka, December $1^{\text {st }}, 2004$

[22]. Uddin, N. (2005). 'History is the Story for Existence: A Case Study of Chittagong Hill Tracts', Asian Profile 33 (4): $391-412$.

[23]. Unrepresented Nations and Peoples Organization (UNPO), "Chittagong Hill Tracts," submission to the U.N. Office of the High Commissioner for Human Rights, Universal Periodic Review: Bangladesh, April 2008, <http://www.uprinfo.org/IMG/pdf/UNPO_BGD_UPR_S4_2009_UnrepresentedNationsandPeoplesOrganization_upr.pdf $>$

[24]. Zahed, I. U. M. (2013), A Theoretical Analysis of Stranded Biharis in Bangladesh: Seeking nationality since four decades, International Journal of Advanced Research, Volume 1, Issue 6, 